Institute of $\mathbf{F}_{\text {ood and }} \mathbf{A}$ gricultural $\mathbf{S}_{\text {ciences }}$

\title{
Brown Recluse Spider, Loxosceles reclusa Gertsch and Mulaik (Arachnida: Araneae: Loxoscelidae) ${ }^{1}$
}

\section{H. V. Weems, Jr. and W. H. Whitcomb ${ }^{2}$ \\ Introduction}

The brown recluse spider, Loxosceles reclusa Gertsch and Mulaik, is one of the few spiders of the south and central United States whose bite is poisonous to man. It is one of the four species of Loxosceles (laeta, gaucho, reclusa, and rufescens) known to be venomous, but probably the venoms of all of the species of the genus are toxic. The bite of the mature female, as in almost all spiders, is more potent than that of the male.

Although the bite of $L$. reclusa usually does not produce such serious and immediate reactions as does the systemic bite of the widow spiders (Latrodectus spp.), a disease, now called necrotic arachnidism or loxoscelism, is caused by its bite. Reactions to the bite vary from mild to very severe. Some victims may not even feel the actual bite, but within a few hours the bitten part usually becomes swollen and painful, and blisters may form on the skin around the bite. The skin at the bite site begins to turn purple, and eventually becomes black and dry as the cells die. Within a few weeks the blackened area flakes away,

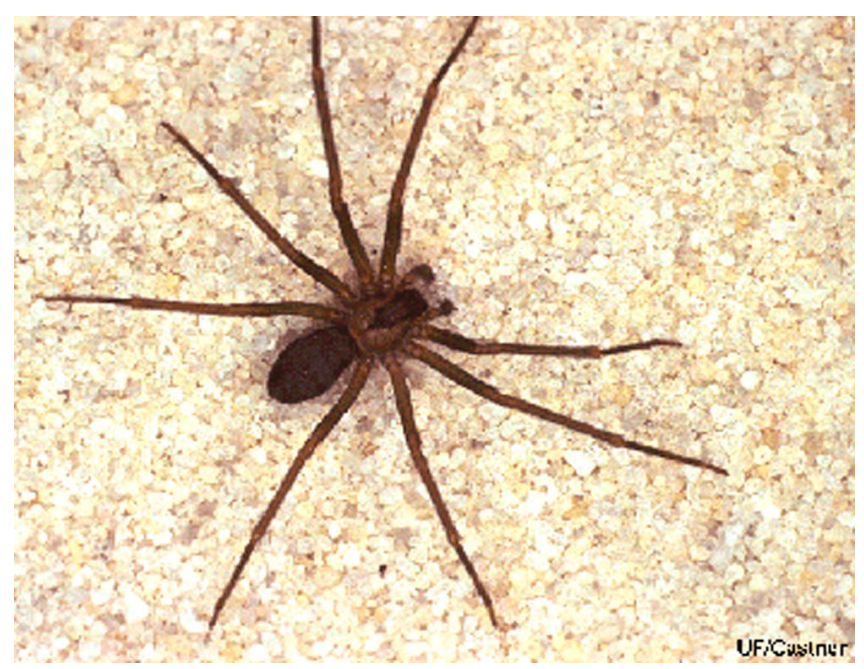

Figure 1. Adult brown recluse spider, Loxosceles reclusa Gertsch and Mulaik. Credits: University of Florida

leaving a circular pit in the skin which fills with scar tissue. The sloughed area, often quite large (up to 30 $\mathrm{mm}$ in diameter), may persist for several weeks, and healing takes place very slowly over a period of several months. A skin graft may be required to prevent a permanent scar.

1. This document is EENY-233 (originally published as DPI Entomology Circular 158), one of a series of Featured Creatures from the Entomology and Nematology Department, Florida Cooperative Extension Service, Institute of Food and Agricultural Sciences, University of Florida. Published: August 2001. Revised: October 2002. This document is also available on Featured Creatures Website at http://creatures.ifas.ufl.edu. Please visit the EDIS Website at http://edis.ifas.ufl.edu. Additional information on these organisms, including many color photographs, is available at the Entomology and Nematology Department website at http://entnemdept.ifas.ufl.edu/.

2. H.V. Weems, Jr., Florida Department of Agriculture and Consumer Services, Division of Plant Industry; and W.H. Whitcomb, Entomology and Nematology Department, University of Florida, Gainesville, FL.

The Institute of Food and Agricultural Sciences is an equal opportunity/affirmative action employer authorized to provide research, educational information and other services only to individuals and institutions that function without regard to race, color, sex, age, handicap, or national origin. For information on obtaining other extension publications, contact your county Cooperative Extension Service office. Florida Cooperative Extension Service/Institute of Food and Agricultural Sciences/University of Florida/Christine Taylor Waddill, Dean. 
Reaction in some persons may be much less severe, consisting only of a local and temporary irritation of the skin, but in others it may be much more severe. In some patients, systematic disturbance of a general nature has been indicated by a rash resembling that of scarlet fever. In a few persons, the venom of the brown recluse spider has caused the destruction of many red blood cells, a very serious complication, signaled by the appearance of bloody or dark-colored urine, according to Gorham (1970). The venom of Loxosceles contains powerful cytotoxins, neurotoxins, and haemotoxins. No antivenin is available. The administration of corticosteroids within 24 hours gives relief. Otherwise, no effective treatment has been found to arrest the necrosis before it has run its course or to promote healing after the dead tissue has been sloughed. Treatment is directed at controlling the symptoms and limiting the amount of tissue destruction.

\section{Synonymy}

Loxosceles reclusus Gertsch and Mulaik 1940: 317.

\section{Distribution}

L. reclusa has been a common spider for many years in parts of Missouri, Kansas, Arkansas, Oklahoma, and Texas, but in recent years it has been spread by man into other parts of the United States, including the southeastern states of Louisiana, Mississippi, Alabama, Georgia, Tennessee, and Kentucky. On many occasions specimens have been inadvertently brought into Florida in trucks and automobiles, hidden in luggage, boxes, and various commercial cargoes, but to date it appears to have been unsuccessful in establishing breeding populations in Florida. An even more venomous species, the South American brown spider, Loxosceles laeta (Nicolet), has been introduced into parts of the United States, including California and Massachusetts, but no established colonies of this species are yet known to occur in the southeastern United States.
Due to of their color and general shape, males of the southern house spider, Kukulcania hibernalis Hentz, are often mistaken for the brown recluse. Southern house spiders are not known to have a dangerous bite. However, two bite cases reportedly caused the victims pain and swelling for a few days.

\section{Identification}

The brown recluse spider is medium-sized with a light brownish or tawny body and dark brown legs. Female body length varies from 7 to $12 \mathrm{~mm}$, averaging about $9 \mathrm{~mm}$; males are similar in size, averaging about $8 \mathrm{~mm}$. Legs rather long and slender and pale to dusky yellow in subadult specimens, with apical segments darker, and dusky orange to dark reddish brown in adults; front legs darker in adults, particularly the males. Legs clothed evenly in fine grayish hairs and typically heavily provided with rows of fine erect blackish setae. Integument of abdomen whitish to yellow, evenly clothed with procumbent dusky brown hairs and thickly set with suberect black setae. The brown recluse has two characteristics that make it easy to recognize -- the front half of its body, the carapace or cephalothorax, bears three pairs of eyes (most other spiders have eight eyes) and a dark, fiddle-shaped marking, the latter characteristic giving rise to the colloquial name "violin spider."

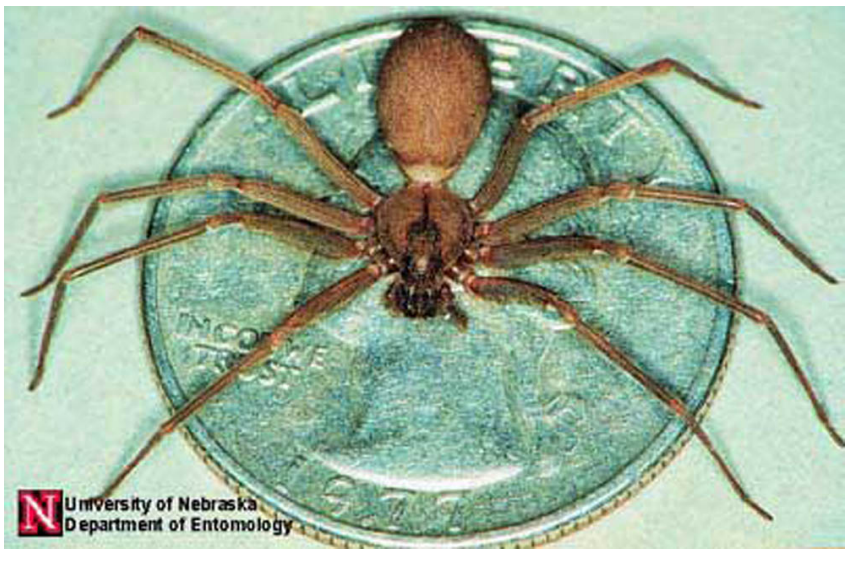

Figure 2. Adult brown recluse spider, Loxosceles reclusa Gertsch and Mulaik. Credits: Jim Kalisch, University of Nebraska - Lincoln (http://entomology.unl.edu/)

\section{Life History, Habits, and Habitat}

Laboratory and field studies conducted in Missouri, Arkansas, and Oklahoma (Hite 1966) indicated that adults and immatures can be found at 


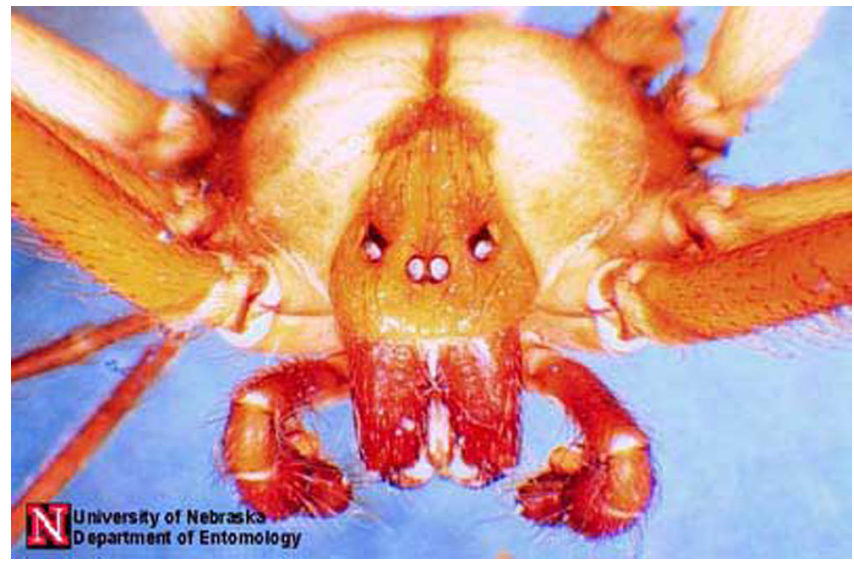

Figure 3. The three pairs of eyes that help identify the brown recluse spider, Loxosceles reclusa Gertsch and Mulaik. Credits: Jim Kalisch, University of Nebraska Lincoln (http://entomology.unl.edu/)

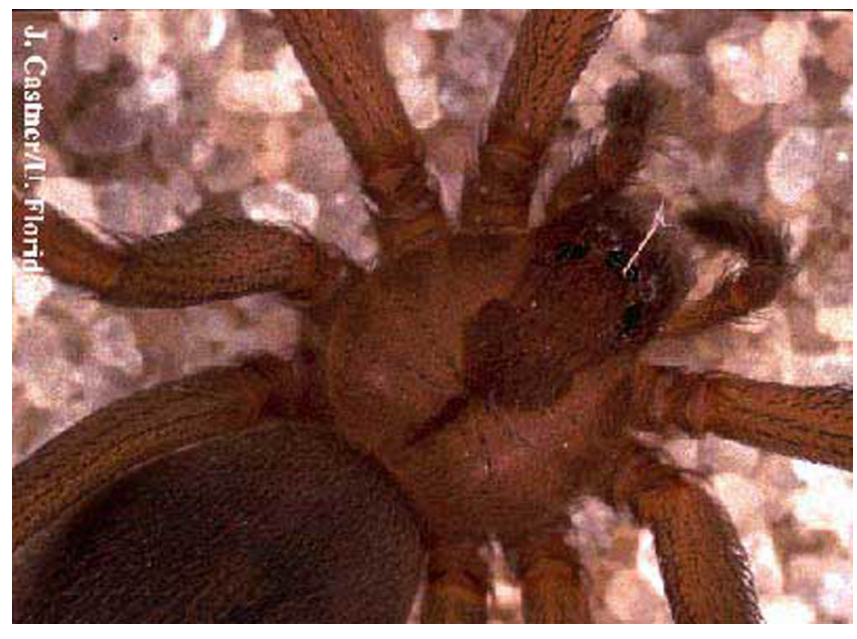

Figure 4. Detail of the carapace of the brown recluse spider, Loxosceles reclusa Gertsch and Mulaik, showing the dark fiddle-shaped marking often used to identify this spider. Credits: J. Castner, University of Florida

all seasons of the year in almost any situation where protection, food, and dryness are adequate, but that mating takes place most commonly in June and July. Females produce from one to five egg sacs, each containing an average of about 50 eggs. The period from oviposition to emergence averages 27 days. Molts required to become adult range from five to eight, including the first molt in the egg sac.

Stadia range from nine to nearly 200 days, the second stadium having the greatest variation. Length of time from oviposition to adulthood averages about 336 days. Males and females occur in nearly equal numbers. The average life span is about $11 / 2$ years, but laboratory-reared females have lived as long as 894 days, and females have lived as long as 297 days without food or water. It is probable that even in outdoor habitats, adults of L. reclusa pass through two winters. Brown recluse spiders are shy, sedentary spiders that are active mostly at night. They spin a large, irregular web with thick, quite sticky threads and place it in some dark situation where the spider remains, using the web both as a retreat and a snare. These loxoscelines are solitary animals, but, in all stages of development, they tend to cluster together in favorable habitats.

In the southern parts of their range they occur commonly outdoors in protected places such as in caves and under rocks, ledges, loose bark, and piles of discarded articles such as old tires and inner tubes, furniture, and various pieces of "junk." they have been found most often in and about houses and other man-made shelters such as bathrooms, bedrooms, closets, cellars, basements, smokehouses, barns, and in any kind of seldom-disturbed storage space in houses and outbuildings. Areas where they may be common include empty boxes, piles of stored papers, in folds of seldom-used clothing hanging in storage areas, behind pictures, and behind old boards leaning against walls. The spiders are not aggressive, and like almost all other spiders, they do not attack people. Accidental bites are suffered most often when the victims are in bed or are putting on clothing in the morning and in the process press against spiders which have taken refuge there. Bites occur most frequently on the arms or legs of the victims. The degree of infestation of these spiders often is in ratio to the neatness and cleanliness of the property owner, so an occasional thorough house cleaning provides the best protection against them.

\section{Selected References}

Baerg, W.J. 1959. The black widow and five other venomous spiders in the United States.

Arkansas Agr. Exp. Sta. Bull. 408: 1-43.

Banks, N. 1910. Catalogue of Nearctic spiders. Bull. U.S. Natl. Mus. 72: 1-80.

D.D. Branscome. (May 1998). IPM for Spiders in Schools. National School IPM. http://schoolipm.ifas.ufl.edu/tp11.htm (21 August 2001) 
Bücherl, W. 1961. Aranhas do gênero Loxosceles e Loxoscelismo na America. Ciência e Cultura 13: 213-224.

D.A. Dame, and T.R. Fasulo. (31 May 2001). Venemous Arthropods. Public Health Pesticide Applicator Training Manual. http://vector.ifas.ufl.edu/chapter_07.htm (21 August 2001).

Dillaha, W., et al. 1964. North American Loxocelism. J. Amer. Med. Ass. 188: 33-36.

Edwards, G.B. (13 August 2002). Chilean recluse, Loxosceles laeta (Nicolet) (Araneae: Sicariidae) in Florida. Pest Alert. http://www.doacs.state.fl.us/ pi/enpp/ento/ loxoscel.html (1 October 2002).

Edwards, G.B. (16 September 2002). Venomous Spiders in Florida .

http://www.doacs.state.fl.us/ pi/enpp/ento/ venomousspiders.htm (20 September 2002).

Gertsch, W.J. 1958. The spider genus Loxosceles in North America, Central American, and the West Indies. Amer. Mus. Novitat. 1907: 1-46.

Gertsch, W.J. 1961. Loxosceles laeta (Nicolet), un nombre válida para la araña causante del loxoscelismo en Sudamérica. Bol. Chileno Parasitol. 16: $1-4$.

Gertsch, W.J. 1967. The spider genus Loxosceles in South America (Araneae, Scytodidae). Bull. Amer. Mus. Nat. Hist. 136: 117-174.

Gertsch, W.J., and S. Mulaik. 1940. The spiders of Texas. I. Bull. Amer. Mus. Nat. Hist. 77: 317.

Gorham, J.R. 1968. The brown recluse spider and necrotic spider bites. J. Environmental Health 31: 138-145.

Gorham, J.R. 1970. The brown recluse. U.S. Dept. Health, Education, and Welfare, Pub. Health Serv., Environmental Health Serv., Environmental Control Admin., U.S. Gov. Printing Office, Washington, D.C. 4 p.
Hite, J.M.R. 1966. The biology of the brown recluse spider, Loxosceles reclusa Gertsch and Mulaik. Unpublished dissertation. Kansas State Univ., Manhattan, KS. p. 1-75.

Hite, J.M., W.J. Gladney, J.L. Lancaster, Jr., and W.H. Whitcomb. 1966. Biology of the brown recluse spider. Arkansas Agr. Exp. Sta. Bull. 711: 1-26.

Horner, N.V., and K.W. Stewart. 1967. Life history of the brown spider, Loxosceles reclusa Gertsch and Mulaik. Texas J. Sci. 19: 333-347.

Jones, S.E. 1936. The Araneida of Dallas County: preliminary note. Field and Lab. 4: 68-70.

Koehler, P.G., D.E.Short and T.R. Fasulo. (1998). Pests In and Around the Home. UF/IFAS. SW-126. CD-ROM.

Lessenden, C.M., Jr., and L.K. Zimmer. 1960. Brown spider bites. J. Kansas Med. Soc. 61: 379-385.

Levi, Herbert W., and A. Spielman. 1964. Amer. J. Trop. Med. Hygiene 13: 132-136.

Morgon, P.N. 1969. Preliminary studies on venom of brown recluse spider. Toxicon 6: 161.

Richman, D.B. 1973. Field studies on the biology of Loxosceles arizonica Gertsch and Mulaik (Araneae, Scytodidae). Arizona Acad. Sci. 8: 124-126.

Schenone, H., A. Rojas, H. Reyes, F. Villarroel, and G. Suarez. 1970. Prevalence of Loxosceles laeta in houses in central Chile. Amer. J. Trop. Med. Hygiene 19: 564-567.

Whitcomb, W.H., and H.K. Wallace. 1972. The occurrence in Florida of the brown recluse spider, Loxosceles reclusa (Araneae: Scytodidae). Ent. News 83: 57-59.

Wingo, C.W. 1964. The status of Loxosceles reclusa, the brown recluse spider, as a public health problem. Proc. North. 